\title{
Biopsychosocial Factors Associated with the Occurrence of Female Infertility
}

\author{
Suci Arsita Sari¹), Uki Retno Budihastuti²), Eti Poncorini Pamungkasari²) \\ 1)Masters Program in Public Health, Universitas Sebelas Maret \\ 2)Department of Obstetrics and Gynecology, Dr. Moewardi Hospital, Surakarta \\ 3)Faculty of Medicine, Universitas Sebelas Maret, Surakarta
}

\begin{abstract}
Background: Infertility is not a disease that needs to be worried. However, it becomes a serious problem for certain people such as causing divorce. Infertility in women can be affected by Polycystic Ovary Syndrome (PCOS), Body Mass Index (BMI), lifestyle, age, occupation, stress, metabolic disorder, endometriosis, and uterine myoma. This study aimed to determine the factors associated with female infertility.

Subjects and Method: This was an analytic observational study with a case control design. This study was conducted at Dr. Moewardi hospital, Surakarta, Central Java, from May to July 2019. A sample of 200 women was selected by fixed disease sampling. The dependent variable was infertility. The independent variables were PCOS, BMI, lifestyle, age, occupation, stress, metabolic disorder, endometriosis, and uterine myoma. The data were collected by questionnaire and medical record. The study was analyzed by a multiple logistic regression.

Results: Female infertility was affected by age $\geq 35$ years $(\mathrm{OR}=9.05 ; 95 \% \mathrm{CI}=2.61$ to $31.39 ; \mathrm{p}=$ o.oo1), occupation $(\mathrm{OR}=8.29 ; 95 \% \mathrm{CI}=2.25$ to $30.48 ; \mathrm{p}=0.001)$, $\mathrm{BMI} \geq 25(\mathrm{OR}=8.16 ; 95 \% \mathrm{CI}=$ 2.44 to $27.29 ; \mathrm{p}=0.001), \mathrm{PCOS}(\mathrm{OR}=117.34 ; 95 \% \mathrm{CI}=10.31$ to $1334.83 ; \mathrm{p}<0.001)$, endometriosis $(\mathrm{OR}=5.01 ; 95 \% \mathrm{CI}=1.17$ to $21.38 ; \mathrm{p}=0.029)$, uterine myoma $(\mathrm{OR}=6.59 ; 95 \% \mathrm{CI}=1.76$ to $24.67 ; \mathrm{p}=$ 0.005), and metabolic disorder $(\mathrm{OR}=15.39 ; 95 \% \mathrm{CI}=4.02$ to $58.84 ; \mathrm{p}<0.001)$.

Conclusion: Female fertility is affected by age $\geq 35$ years, occupation, BMI $\geq 25$, PCOS, endometriosis, uterine myoma, and metabolic disorder.
\end{abstract}

Keywords: female infertility, PCOS, endometriosis

\section{Correspondence:}

Suci Arsita Sari. Masters Program in Public Health, Universitas Sebelas Maret. Jl. Ir. Sutami 36 A, Surakarta 57126, Central Java. Email: suciarsita@gmail.com. Mobile: 085786179994

\section{BACKGROUND}

A family is incomplete without the presence of a child. A child brings together the harmony of a family. The presence of a child is very important for the family. However, not all families get offspring naturally. Infertility is not considered a disease that needs to be worried, but it can be a serious problem for certain people and also causes a divorce (Vita-health, 2007). According to the National Commission on Violence Against Women (2016), in 2015, Indonesia had802 cases of divorce which were caused by infertility.
World Health Organization (2013) states there are 48.5 million couples in the world having infertility problem. The occurrence of infertility in developing countries is high. It reaches $30 \%$. However, the occurrence of infertility in developed countries is only $5-8 \%$. The infertility level in Indonesia is $21.3 \%$ out of the total population of reproductive age. It can be assumed that 2 out of 10 couples of reproductive age are infertile. The high level of infertility is assumed to increase with changes on existing demographic patterns. 
Infertility is the failure of a couple to get pregnant within 1 year or more of a marriage, after having sexual intercourse regularly without using any contraception method (Prawirohardjo, 2011). Infertility can be caused by men and women. The percentage of factors that can cause male infertility is $30-40 \%$, while from female is 60-70\% (Manuaba, 2010). The level of female infertility in Indonesia reached $15 \%$ or around 6 million Indonesian women experiencing infertility (Indonesia Demographic and Health Survey, 2012). Female infertility is caused by age, occupation, stress level, BMI, abnormalities of the reproductive organ, comorbidity lifestyle, ovulation disorders (PCOS), tubal disorders, and uterine disorders (Oktarina et al., 2014; Indarwati et al., 2017; Hestiantoro et al., 2013).

There are several factors affecting the risks of female infertility. According to Santoso et al. (2014), 75\% of female infertility are caused by PCOS. PCOS (Polycystic Ovary Syndrome) is associated with ovulation disorders in a woman of reproductive age. The absence of ovulation for 35 days to 6 months reduces the chance of sperm meeting with the ovum; therefore, it causes infertility (SListina et al., 2016).

Infertility is also caused by nutritional status. BMI (Body Mass Index) is used to assess a person's nutritional status. Abnormal nutritional status will affect on the delayed fertilization (Ahsan et al., 2012). The obesity rate in Indonesia has increased from year to year by $10.5 \%$ in 2007 and $21 \%$ in 2018. Chronic energy deficiency in women of reproductive age is also quite high, which is $14.5 \%$ (Ministry of Health, 2018).

Nutritional status can affect a person's immunity, thus making her/him susceptible to disease. The most common non-infectious diseases in infertility women are endometriosis (25.6\%) and uterine myoma. After removing the disease, the scar tissue will appear, thus inhibiting fertilization (Oktarina et al., 2014).

Another factor that affect female infertility is age. If a woman is still in the reproductive period and having regular menstruation, pregnancy is likely to occur. Increasing age will reduce a woman's ability to get pregnant (Saraswati, 2015). In addition, the risky jobs increase the incidence of female infertility. There are several occupations that related to exposures to dangerous substancesfor female fertility. The substances that have been identified and can affect fertility are heat, X-ray radiation, metals, and pesticides (Hestiantoro et al., 2013). Jobs with high workloads can increase stress level to depression. The prevalence of depression in Indonesia is $6.1 \%$ and $9 \%$ of them have medical treatment (Ministry of Health, 2018). Stress is a condition where there is a pressure on someone can lead to various reactions. One of the effects of stress is affecting body functions, including the reproductive system. If it happens to women, it will affect the female fertility (Indarwati et al., 2017).

Several studies related to infertility have been carried out. However, various complex causative factors make the incidence of infertility in Indonesia still high. Therefore, the further study on the analysis of risk factors for female infertility is needed. This study aimed to analyze the risk factors associated with the occurrence of female infertility.

\footnotetext{
SUBJECTS AND METHOD

\section{a. Study Design}

This was an analytic observational study with a case control design. The study was conducted at Dr. Moewardi Hospital from May to July 2019.
} 


\section{b. Population and Sample}

The case population in this study was all infertile female patients at Dr. Moewardi Hospital. The control population was all fertile female patients at Dr. Moewardi Hospital. A sample of 200 female was selected by fixed disease sampling.

\section{c. Study Variables}

The dependent variable was female infertility. The independent variables were age, occupation, BMI, PCOS, endometriosis, uterine myoma, and metabolic disorder.

\section{d. Operational Definition of variables} Female infertility was a failure of a woman who has never been pregnant or has ever been pregnant to get another pregnancy after at least 12 months of sexual intercourse regularly without using any contraception. The data were collected by medical record. The measurement scale was categorical.

\section{Polycystic Ovary Syndrome (PCOS)} wasa group of symptoms of chronic ovulation disorders, hyper-androgenemia, and polycystic ovary morphological features experienced by women of reproductive age. It could interfere with fertility. The data were collected by medical record. The measurement scale was categorical.

Body Mass Index (BMI) was one of the methods used to measure a person's nutritional status by comparing weight and height. The measurement scale was continous and transformed into dichotomous.

Life style was a person's lifestyle that was expressed in her activities, interests, and opinions. The examples were smoking habits, alcohol consumption, balanced diet, exercise, rest patterns, drugs consumption. The data were collected by questionnaire. The measurement scale was continous and transformed into dichotomous.

Age was the time duration since birth to the study was carried out in units of years. The data were collected by questionnaire.
The measurement scale was continous and transformed into dichotomous.

Occupation was the main activity that was carried out everyday. The data were collected by questionnaire. The data were collected by medical record. The measurement scale was categorical.

Stress was a mental disorder faced by a person due to pressure. The data were collected by the Perceived Stress Scale questionnaire. The measurement scale was continous and transformed into dichotomous.

Metabolic disorder was a metabolic disease suffered by women who experienced natural inability to get pregnant, such as diabetes, hypertension, and heart disease. The data were collected by medical record. The measurement scale was categorical.

Endometriosis was the growth of glands and endometrial stroma that still had function outside the uterine cavity and the myometrium. The data were collected by medical record. The measurement scale was categorical.

Uterine myoma was a benign and solid uterine muscle tumor that grew in the uterus. The data were collected by medical record. The measurement scale was categorical.

\section{e. Study Instrument}

The data were collected by the researcher using primary data from questionnaires for the age and occupation variables. BMI data collection was carried out with height and weight measurement. Height was measured by measuring height. Weight was measured by a scale. Other variables were collected by medical records.

\section{f. Data Analysis}

Univariate analysis aimed to describe the characteristics of each variable. Continuous data were described in n, Mean, SD, Min, and Max. Categorical data were described 
in $\mathrm{n}$ and percentage (\%). Bivariate analysis in this study was conducted to determine the correlation between female infertility and independent variables using the chisquare test. Multivariate data analysis used multiple logistic regression analysis.

\section{g. Research Ethics}

The research ethics in this study included the approval sheet, anonymity, confidentiality, and research ethics. The ethical eligibility in this study was from the Health Research Ethics Committee of Dr. Moewardi Hospital number: 493/IV/HREC/2019.

\section{RESULTS}

\section{Sample Characteristic}

Table 1 shows the frequency distribution of age, lifestyle, stress, and BMI variables in

Table 1. The frequency distribution of the continous data variables

\begin{tabular}{lccccc}
\hline \multicolumn{1}{c}{ Variables } & n & Mean & SD & Min & Max \\
\hline Usia (tahun) & 200 & 32.0 & 6.1 & 17.0 & 50.0 \\
IMT & 200 & 23.9 & 3.7 & 17.2 & 36.2 \\
\hline
\end{tabular}

Table 2.The frequency distribution of the categorical data variables

\begin{tabular}{|c|c|c|}
\hline Characteristic & Frequency & Percentage (\%) \\
\hline \multicolumn{3}{|l|}{ Age } \\
\hline$<35$ years & 141 & 70.5 \\
\hline$\geq 35$ years & 59 & 29.5 \\
\hline \multicolumn{3}{|l|}{ Occupation } \\
\hline Unemployed & 92 & 46 \\
\hline Employee & 108 & 54 \\
\hline \multicolumn{3}{|l|}{ Body Mass Index } \\
\hline $18.5-25$ & 141 & 70.5 \\
\hline$<18.5$ or $\geq 25$ & 59 & 29.5 \\
\hline \multicolumn{3}{|l|}{ Infertility } \\
\hline No & 150 & 75 \\
\hline Yes & 50 & 25 \\
\hline \multicolumn{3}{|l|}{ Polycystic Ovary Syndrome } \\
\hline No & 177 & 88.5 \\
\hline Yes & 23 & 11.5 \\
\hline \multicolumn{3}{|l|}{ Endometriosis } \\
\hline No & 174 & 87 \\
\hline Yes & 26 & 13 \\
\hline \multicolumn{3}{|l|}{ Uterine Myoma } \\
\hline No & 174 & 87 \\
\hline Yes & 26 & 13 \\
\hline \multicolumn{3}{|l|}{ Metabolic disorder } \\
\hline No & 166 & 83 \\
\hline Yes & 34 & 17 \\
\hline
\end{tabular}

continuous data. The age of 200 study subjects had a mean by 32.04 , SD by 6.08 , lowest age by 17 years, and highest age by 50 years. BMI in 200 study subjects had a mean by 23.94 , SD by 3.73 , lowest BMI by 17.2 and highest BMI by 36.2

The frequency distribution of study variables with categorical data is presented in Table 2. Female who were in the reproductive age $(<35$ years) were $70.5 \%$, who worked were $54 \%$, who had normal BMI were $70.5 \%$, who were diagnosed as infertile as a case group were $25 \%$ and as fertile as a control group were $75 \%$. The study subjects who had Polycystic Ovary Syndrome were $11.5 \%$, had endometriosis were $13 \%$, had uterine myoma were $13 \%$, and had metabolic disorder were $17 \%$. 


\section{Bivariate Analysis}

Table 3 shows the result of a bivariate analysis of various factors related to infertility. Female infertility was significantly affected by age $\geq 35$ years $(\mathrm{OR}=4.88$; $\mathrm{p}<0.001)$, occupation ( $\mathrm{OR}=8.03$; $\mathrm{p}<0.001)$, unhealthy lifestyle $(\mathrm{OR}=2.92 ; \mathrm{p}=0.001)$, high stress $(\mathrm{OR}=2.17 ; \mathrm{p}=0.034), \mathrm{BMI} \geq 25(\mathrm{OR}=7.10 ; \mathrm{p}$ $<0.001)$, PCOS (OR=117.07; $\mathrm{p}<0.001)$, endometriosis $(\mathrm{OR}=2.53 ; \mathrm{p}=0.029)$, uterine myoma $(\mathrm{OR}=3.70 ; \mathrm{p}=0.002)$, and metabolic disorder $(\mathrm{OR}=15.60 ; \mathrm{p}<0.001)$.

\section{Multivariate Analysis}

Table 4 shows the result of multivariate analysis of various factors related to infertility. Women aged $\geq 35$ years had a greater risk for having infertility (OR=9.05; 95\% $\mathrm{CI}=2.61$ to $31.39 ; \mathrm{p}=0.001)$. Women who worked had a greater risk for having infertility than women who did not work (OR= 8.29; $95 \% \mathrm{CI}=2.25$ to $30.48 ; \mathrm{p}=0.001)$.
Women with $\mathrm{BMI}$ of $\geq 25$ had a greater risk for having infertility than BMI of 18.5 to 25 $(\mathrm{OR}=8.16 ; 95 \% \mathrm{CI}=2.44$ to $27.29 ; \mathrm{p}=$ 0.001).

Women with PCOS had a greater risk for having infertility than those without $\operatorname{PCOS}(\mathrm{OR}=117.34 ; 95 \% \mathrm{CI}=10.31$ to 1334.83; $\mathrm{p}<0.001)$. Women who had endometriosis were at greater risk for having infertility than those who did not have endometriosis $(\mathrm{OR}=5.01 ; 95 \% \mathrm{CI}=1.17$ to 21.38; $\mathrm{p}=0.029)$. Women who had uterine myoma were at greater risk for having infertility than those who did not have uterine myoma $(\mathrm{OR}=6.59 ; 95 \% \mathrm{CI}=1.76$ to 24.67; $\mathrm{p}=0.005)$. Women who had metabolic disorder were at greater risk for having infertility than those who did not have metabolic disorder (OR=15.39; 95\% $\mathrm{CI}=4.02$ to $58.84 ; \mathrm{p}<0.001)$.

Table 3. The result of the bivariate analysis of the risk factors of female infertility

\begin{tabular}{|c|c|c|c|c|c|c|c|c|}
\hline \multirow{3}{*}{ Independent Variables } & \multicolumn{4}{|c|}{ Infertility } & \multirow{2}{*}{\multicolumn{2}{|c|}{ Total }} & \multirow{3}{*}{$\mathbf{O R}$} & \multirow{3}{*}{$\mathbf{p}$} \\
\hline & \multicolumn{2}{|c|}{ Fertile } & \multicolumn{2}{|c|}{ Infertile } & & & & \\
\hline & $\mathbf{N}$ & $\%$ & $\mathbf{n}$ & $\%$ & $\mathbf{n}$ & $\%$ & & \\
\hline \multicolumn{9}{|l|}{ Age } \\
\hline$<35$ years & 119 & 84.4 & 22 & 15.6 & 141 & 100 & \multirow[t]{3}{*}{4.88} & \multirow[t]{3}{*}{$<0.001$} \\
\hline$\geq 35$ years & 31 & 52.5 & 28 & 47.5 & 59 & 100 & & \\
\hline \multicolumn{7}{|l|}{ Occupation } & & \\
\hline Unemployed & 85 & 92.4 & 7 & 7.6 & 92 & 100 & \multirow[t]{3}{*}{8.03} & \multirow[t]{2}{*}{$<0.001$} \\
\hline Employee & 65 & 60.2 & 43 & 39.8 & 108 & 100 & & \\
\hline \multicolumn{7}{|l|}{ Body Mass Index } & & \\
\hline $18.5-25$ & 122 & 86.5 & 19 & 13.5 & 141 & 100 & \multirow[t]{3}{*}{7.10} & \multirow[t]{2}{*}{$<0.001$} \\
\hline$<18.5$ or $\geq 25$ & 28 & 47.4 & 31 & 52.5 & 59 & 100 & & \\
\hline \multicolumn{7}{|l|}{ Infertility } & & \\
\hline No & 149 & 84.2 & 28 & 15.8 & 177 & 100 & \multirow[t]{2}{*}{117.07} & \multirow[t]{2}{*}{$<0.001$} \\
\hline Yes & 1 & 4.3 & 22 & 51.9 & 23 & 100 & & \\
\hline \multicolumn{7}{|l|}{ Polycystic Ovary Syndrome } & & \\
\hline No & 135 & 77.6 & 39 & 22.4 & 174 & 100 & \multirow[t]{3}{*}{2.53} & \multirow[t]{2}{*}{0.029} \\
\hline Yes & 15 & 57.7 & 11 & 42.3 & 26 & 100 & & \\
\hline \multicolumn{7}{|l|}{ Endometriosis } & & \multirow{4}{*}{0.002} \\
\hline No & 137 & 78.7 & 37 & 21.3 & 174 & 100 & \multirow[t]{3}{*}{3.70} & \\
\hline Yes & 13 & 50 & 13 & 50 & 26 & 100 & & \\
\hline \multicolumn{7}{|l|}{ Uterine Myoma } & & \\
\hline No & 141 & 84.9 & 25 & 15.1 & 166 & 100 & \multirow[t]{2}{*}{15.60} & \multirow[t]{2}{*}{$<0.001$} \\
\hline Yes & 9 & 26.5 & 25 & 73.5 & 34 & 100 & & \\
\hline
\end{tabular}


Table 4.The result of the analysis of multiple logistic regression of the risk factors of female infertility

\begin{tabular}{lcccc}
\hline \multirow{2}{*}{$\begin{array}{c}\text { Independent } \\
\text { Variables }\end{array}$} & \multirow{2}{*}{ OR } & \multicolumn{2}{c}{ 95\% CI } & p \\
\cline { 3 - 4 } & & Lower limit & Upper limit & 0.001 \\
Age ( $\geq 35$ years) & 9.05 & 2.61 & 31.39 & 0.001 \\
Occupation (Yes) & 8.29 & 2.25 & 30.48 & 0.001 \\
BMI ( $\geq 25$ 25) & 8.16 & 2.44 & 27.29 & $<0.001$ \\
PCOS (Yes) & 117.34 & 10.31 & 1334.83 & 0.029 \\
Endometriosis (Yes) & 5.01 & 1.17 & 21.38 & 0.005 \\
Uterine myoma (Yes) & 6.59 & 1.76 & 24.67 & $<0.001$ \\
Metabolic disorder (Yes) & 15.39 & 4.02 & 58.84 & \\
N observation $=200$ & & & & \\
Log likelihood $=-44.23$ & & & & \\
\hline
\end{tabular}

\section{DISCUSSION}

\section{The effect of age on female infertility}

Based on the result of the analysis, age had a significant effect on female infertility. The age of $\geq 35$ years increased the risk of infertility in women.

According to Deyhoul et al., (2017), the risk of infertility increases with age. A woman at the age of $>30$ has a greater risk of pregnancy failure. It is in line with a study conducted by Crawford et al., (2015). The fecundity or ability to get pregnant decreases with age. Women who have never been pregnant have a lower chance of achieving pregnancy. The fecundity decreases significantly at the end of 30 years of age and at the early age of 40 years. The probability of infertility increases from $10 \%$ to $20 \%$ at age $>35$ years and to $45 \%$ at the early age of 40 years (Steiner et al., 2016)

\section{The effect of occupation on female infertility}

Based on the result of the analysis, occupation affected female infertility. Women who worked were at a greater risk for having infertility than women who did not work.

Some occupations that involve exposures to dangerous substancescan increase the risk of infertility. The substances that have been identified and can affect fertility are heat, X-ray radiation, metals, and pesticides. Occupations that can increase the risk of female infertility are paramedics, office workers, and farmers (Hestiantoro et al., 2013). According to Fernandez et al. (2016), working with a shift work system causes menstrual disorders and the risk factor of miscarriage.

\section{The effect of BMI on female infertility}

Based on the result of the analysis of the study data, BMI had a significant effect on female infertility. BMI $\geq 25$ increased the risk of infertility in women.

This study is in line with the study result conducted by Fontana et al. (2016) that abnormal BMI such as undernutrition, overnutrition, and obesity affect fertility in women. It is related to changes in metabolism in the reproductive system. Fatty acids, carbohydrates, and proteins have their ways of working. If the intake is not balanced quantitatively or qualitatively, it can damage the homeostatic metabolism and fertility in women.

4. The effect of Polycystic Ovary Syndrome on female infertility Infertility was significantly affected by Polycystic Ovary Syndrome (PCOS). PCOS increased the risk of infertility in women.

PCOS is a group of symptoms of chronic ovulation disorders, hyper-andro- 
genemia, and polycystic ovary morphological features (Heffner, 2010). According to Wang et al. (2019), the presence of perfluorododecanoic acid in plasma increases the risk of infertility in women with PCOS. According to Wang et al. (2017) in another study, PCOS can also cause infertility due to an-ovulation in PCOS sufferers. Therefore, the fertilization cannot occur. An-ovulation in women with PCOS is a result of hormonal disorders in the body (Heffner et al., 2010).

\section{The effect of endometriosis on female infertility}

Based on the result of the study analysis, endometriosis had a significant effect on female infertility. Endometriosis increased the risk of infertility in women.

The result of this study is in line with a study conducted by Zhou et al. (2018) that patients with endometriosis have 3 times greater risk for having infertility than those who do not have endometriosis. Concentration of Perfluorobutane Sulfonic Acid (PFBS) in plasma on the endometriosis increases the risk of female infertility (Wang et al., 2017). Endometriosis can also cause ovulation disorders; thus decreasing the ability to get pregnant (Conto et al., 2017). In addition, female infertility is also caused by scar tissue due to surgical removal of endometriosis (Hart, 2019).

\section{The effect of uterine myoma on female infertility}

Uterine myoma was significantly affected on female infertility. Uterine myoma increased the risk of infertility in women.

This study is in line with a study by Lisiecki et al. (2017) that uterine myoma with a large size and proportion can increase uterine stretching. This stretching causes contractility in the uterus. It has implications for the implantation disorders of fertilization. As a result, uterine myoma becomes one of the risk factors associated with the occurrence of female infertility.

\section{The effect of metabolic disorder on female fertility}

Metabolic disorders affected female infertility. Metabolic disorders increased the risk of infertility in women.

Infertility is associated with cardiovascular disease due to metabolic dysfunction in the body (Hanson et al., 2017). Thyroid dysfunction is also associated with reproductive disorders. 1 out of 8 women with hypothyroidism experience infertility. The thyroid antibodies in patients with hypothyroidism cause difficulty of getting pregnant, implantation failure, and risk of miscarriage (Hart, 2019).

\section{AUTHOR CONTRIBUTION}

Suci Arsita Sariis the main researcher who plays a role in collecting and processing the data of the study. Uki Retno Budihastuti examined the conceptual framework and methodology of the study. Eti Poncorini Pamungkasari gave the suggestion related to the discussion.

\section{FUNDING AND SPONSORSHIP}

This study used independent fund by the main researcher.

\section{CONFLICT OF INTEREST}

There is no conflict of interest.

\section{ACKNOWLEDGEMENT}

We thank the hospital for helping to make this research run well, as well as for patients who have participated and are willing to become the study subjects.

\section{REFERENCE}

Ahsan, Hakim BA, Tamar M (2012). Faktor risiko yang memengaruhi keterlambatan konsepsi (infertilitas) pasangan 
suami istri padalaki-laki di kecamatan palu utara kota palu. Tesis. Makassar: Fakultas Kesehatan Masyarakat Universitas Hasanuddin. Retrieved from http://pasca.unhas.ac.id/jurnal/files/da49f6o8a6792fb121327ca6ab852972.pdf

Conto ED, Matte U, Bilibio JP, Genro VK, Souza CA, Leao DP, Filho JSC (2017). Endometriosisassociated infertility: GDF-9, AMH, and AMHR2 genes polymerphisms. J Assist Reprod Gen, 34(12): 1667-1672. Retrieved from https://doi.org/10.1007/s10815-0171026-z.

Crawford NM, Steiner AZ (2015). Agerelated infertility. Obstet Gyn Clin NAM, 42(1): 15-25. Retrieved from https://doi.org/10.1016/j.ogc.2014.09.005.

Deyhoul N, Mohammaddoost T, Hosseini $M$ (2017). Infertility-related risk factors : a systematic review. Int $J$ Women Health Reprod Sci, 5(1): 24-29. Retrieved from https://doi.org/10.15296/ijwhr.2017.05.

Fernandez RC, Marino JL, Davis S, Moran LJ, Rumbold AR, Brown HM, Whitrow MJ, Moore VM (2016). Fixed or rotating night shift work undertaken by women: implications for fertility and miscarriage. Semin Reprod Med, 34(2): 74-82. Retrieved fromhttps://doi.org/10.1055/s-0036-1571354

Fontana R, Torre SD (2016). The deep correlation between energy metabolismand reproduction: a view on the effects of nutritionfor women fertility. Nutrients, 8(2): 87-97. Retrieved from https://doi.org/10.3390/nu8020087.

Hanson B, Johnstone E, Dorais J, Silver B, Peterson CM, Hotaling J (2017). Female infertility, infertility associated diagnoses, and comobdities : a review.
J Assist Reprod Gen, 34(2): 167-177. Retrieved fromhttps://doi.org/10.1007/s10815-016-0836-8

Hart JR (2016). Physiological aspects of female fertility:role of the environment, modernlifestyle, and genetics. Psychol Rev, 96 (3): 873-909. Retrieved from https://doi.org/10.1152/physrev.00023.2015.

Heffner LJ, Schust DJ (2010). At a glance sistem reproduksi. Edisi kedua. Jakarta: Erlangga Medical Series.

Hestiantoro A, Soebijanto S (2013). Konsensus penanganan infertilitas. HIFERI, PERFITRI, IAUI dan POGI. Retrieved from https://pogi.or.id/publish/download/pnpk-dan-ppk/

Indarwati I, Hastuti URB, Dewi YLR (2017). Analysis of factors influencing female infertility. $J$ Matern Child Health 2(2): 150-161. Retrieved from https://doi.org/10.26911/thejmch.2017.02.02.06.

Kementerian Kesehatan (2018). Hasil utama riskesdas 2018. Kementerian Kesehatan: Badan Penelitian dan Pengembangan Kesehatan. Retrieved from http://www.depkes.go.id/resources/download/infoterkini/materi_r akorpop_2018/Hasil\%20Riskesdas\% 202018.pdf diakses pada 20 Februari 2019.

Lisiecki M, Paszkowski M, Wozniak S (2017). Fertility impairment associated with uterine fibroids-a review of literature. Menopause Rev, 16(4): 137140. Retrieved from https://doi.org/10.5114/pm.2017.72759.

Manuaba IAC (2010). Ilmu kebidanan, penyakit kandungan dan KB. Edisi kedua. Jakarta: EGC.

Oktarina A, Abadi A, Bachsin R (2014). Faktor-faktor yang memengaruhi infertilitas pada wanita di kilinik fertilitas endokrinologi reproduksi. MKS, 
46 (4). Retrieved fromhttps://ejournal.unsri.ac.id/index.php/mks/article/view/2722.

Prawirohardjo S (2011). Ilmu kandungan. Edisi kedua. Jakarta: PT Bina Pustaka.

Saftarina F, Putri INW (2016). Effect of polycistic ovary syndrome to increase infertility risk factors. Majority, 5(2): 43-48. Retrieved from http://juke.kedokteran.unila.ac.id/index.php/majority/article/view/1076

Santoso B (2014). Sindroma ovarium polikistik:problem reproduksi dan tantangannyaterkait dengan gaya hidupperempuan indonesia. Fakultas Kedokteran Universitas Airlangga. Retrieved fromhttp://repository.unair.ac.id/id/eprint/40072

Saraswati A (2015). Infertility. Majority, 4(5). Retrieved from http://juke.kedokteran.unila.ac.id/index.php/major ity/article/view/601

SDKI (2012). Survey demografi dan kesehatan indonesia. Jakarta : Badan Pusat Statistik. Retrieved fromhttp://kesga.kemkes.go.id/images/pedoman/SDKI\%202012-Indonesia.pdf

Steiner AZ, Jukic AM (2016). Impact of female age and nulligravidity on fecundity in an olderreproductive age cohort. Fertil Steril, 105(6): 1584-1588. Retrieved from https://doi.org/10.1016/j.fertnstert.2016.02.028

Vitahealth (2007). Infertil. Jakarta : PT Gramedia Pustaka Utama.

Wang B, Zhang R, Jin F, Lou H, Mao Y, Zhu W, Zhou W, Zhang P, Zhag J (2017).
Perfluoroalkyl substances and endometriosis-related infertility in chinese women. Environ Int, 102: 207-212. Retrieved from https://doi.org/10.1016/j.envint.2017.03.003

Wang R, Mol BW (2017). The rotterdam criteria for polycystic ovary syndrome: evidence-based criteria?. Hum Reprod, 32(2): 261-264. Retrieved fromhttps://doi.org/10.1093/humre$\mathrm{p} /$ dew287

Wang W, Zhou W, Wu S, Liang F, Li Y, Zhang J, Cui L, Feng Y, Wang Y (2019). Perfluoroalkyl substances exposure and risk of polycystic ovarian syndrome related infertility in chinese women. Environ Pollut, 247: 824-831. Retrieved from https://doi.org/10.1016/j.envpol.2019.01.039

World Health Organization (WHO) (2013). Infertility/subfertility:extract frommeeting to develop a global consensus on preconception care to reduce maternal and childhood mortality and morbidity. Retrieved fromhttp://www.who.int/entity/reproductiveheal th/publications/infertility/978924150 5000_annex3/en/.

Zhou Z, Zheng D, Wu H, Li R, Xu S, Kang Y, Cao Y, Chen X, Zhu Y, Xu S, Chen ZJ, Mol BW, Qiao J (2018). Epidemiology of infertility in China:a populationbased study. Int $\mathrm{J}$ Gynecol Obstet, 125(4): 432-441. Retrieved fromhttps://doi.org/10.1111/14710528.14966 